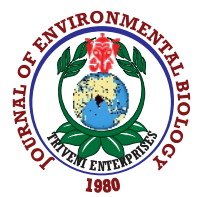

\title{
Effects of heavy metals on diesel metabolism of psychrotolerant strains of Arthrobacter sp. from Antarctica
}

\author{
M. Abdulrasheed ${ }^{1,2}$, A.F. Roslee', N.N. Zakaria ${ }^{1}$, A. Zulkharnain ${ }^{3}$, G.L.Y. Lee', P. Convey ${ }^{4}$, S. Napis ${ }^{5}$ and S.A. Ahmad ${ }^{1 \%}$ \\ 'Department of Biochemistry, Faculty of Biotechnology and Biomolecular Sciences, Universiti Putra Malaysia, 43400 UPM Serdang, Malaysia \\ ${ }^{2}$ Department of Microbiology, Faculty of Science, Gombe State University, P.M.B 127, Gombe State, Nigeria \\ ${ }^{3}$ Department of Bioscience and Engineering, College of Systems Engineering and Science, Shibaura Institute of Technology, 307 Fukasaku, \\ Minuma-ku, Saitama, 337-8570, Japan \\ "British Antarctic Survey, NERC, High Cross, Madingley Road, Cambridge CB3 OET, UK \\ ${ }^{5}$ Department of Cell and Molecular Biology, Faculty of Biotechnology and Biomolecular Sciences, Universiti Putra Malaysia, 43400 UPM Serdang, \\ Selangor, Malaysia \\ *Corresponding Author Email : aqlima@upm.edu.my
}

\begin{tabular}{lll}
\hline Paper received: 04.11.2019 & Revised received: 06.04.2020 & Accepted: 15.04 .2020 \\
\hline
\end{tabular}

\section{Abstract}

Aim: This present study aimed at examining the ability of cold-adapted Antarctic bacteria to tolerate and degrade diesel in the presence of different types of heavy metal co-pollutants.

Methodology: Arthrobactersp. strains AQ5-05 and AQ5-06, originally isolated from Antarctic soils, were grown on Bushnell-Haas medium containing 1 ppm of heavy metal ions (As, $\mathrm{Ag}, \mathrm{Cd}, \mathrm{Co}, \mathrm{Cu}, \mathrm{Cr}, \mathrm{Hg}, \mathrm{Ni}$, and $\mathrm{Pb})$ supplemented with $3 \%(\mathrm{v} / \mathrm{v})$ diesel. Diesel degradation was determined gravimetrically, while bacterial growth was evaluated by measuring the optical density of media $\left(\mathrm{OD}_{600 \mathrm{~mm}}\right)$.

Results: In the absence of heavy metal ions, strain AQ5-06 achieved $37.5 \%$ diesel mineralisation, while strain AQ5-05 achieved $34.5 \%$. The diesel degrading abilities of both strains were significantly inhibited by exposure to $<1 \mathrm{ppm}$ of $\mathrm{Ag}$ or $\mathrm{Hg}$. In contrast, no change in degradation ability was observed using other tested heavy metals. The $\mathrm{IC}_{50}$ of $\mathrm{Ag}$ and $\mathrm{Hg}$ on diesel degradation by the two strains were $(0.2$ and $0.4 \mathrm{ppm})$ and (0.3 and $0.2 \mathrm{ppm})$, respectively.

Interpretation: Arthrobacter sp. Strains AQ5-05 and AQ5-06 may contain genes for alkane degradation and heavy metal resistance for remediating diesel-polluted soil in Antarctic and other cold regions.

Keywords: Antarctica, Arthrobacter sp., Biodegradation, Diesel, Heavy metals

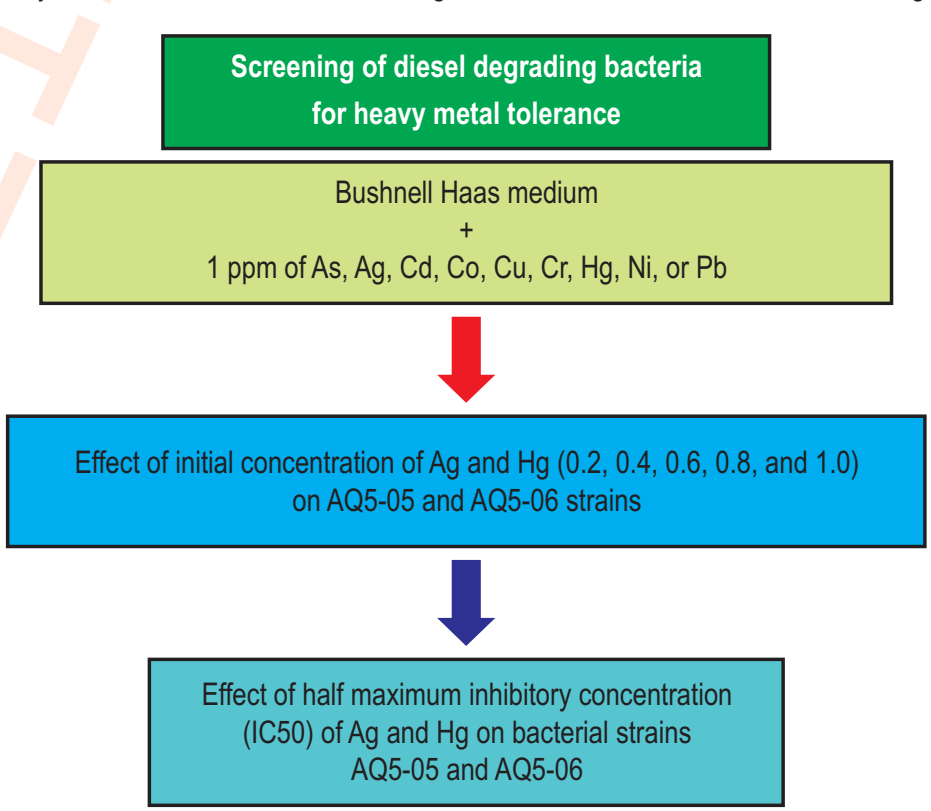

How to cite : Abdulrasheed, M., A.F. Roslee, N.N. Zakaria, A. Zulkharnain, G.L.Y. Lee, P. Convey, S. Napis and S.A. Ahmad: Effects of heavy metals on diesel metabolism of psychrotolerant strains of Arthrobacter sp. from Antarctica. J. Environ. Biol., 41, 966-972 (2020). 


\section{Introduction}

Antarctica remains the only largely unpolluted part of the Earth. Even so, areas within the continent have been contaminated by petroleum hydrocarbons, notably diesel oil, associated with anthropogenic activities through national governmental research stations as well as the rise in tourism in recent decades, both primarily supported by ships (Prus et al., 2015; Mazuki et al., 2019). Petroleum hydrocarbons are the major source of energy used to run facilities in Antarctica and the primary source of hydrocarbon pollution in this region (Snape et al., 2001; Ruberto et al., 2005). Diesel oil, the most often used hydrocarbon fuel in the Antarctic region, consists of a complex mixture of aliphatic and aromatic hydrocarbons and is made by the fractional distillation of petroleum (Gallego et al., 2001). It also contains toxic compounds including phenolics that tend to persist in contaminated environments along with heavy metals including cadmium, chromium and lead, and other persistent organic pollutants (POPs) such as hexachlorobenzene and hexachlorocyclhexanes (Lee et al., 1992, Bargagli, 2008; Corsolini, 2009; Zakaria et al., 2019).

Heavy metals have been reported to alter the activities of Antarctic microbial communities and affect the enzymes involved in different metabolic processes, including the impairment of microbial diesel degradation (Kandeler et al., 1996; Hong et al., 2012, Riis et al., 2002). In addition, they negatively affect microbial growth, morphology and metabolism in soils by denaturing proteins and causing functional disruption, as well as destroying the integrity of cell membrane (Murthy et al., 2014; Pandey et al., 2011; Sha'arani et al., 2019). Heavy metals are not only capable of polluting native soil and water near areas of industrial activity but may also be carried away to longer distances through atmosphere (Hong et al., 2012; Zhou et al., 2015; Zhang et al., 2018, Darham et al., 2019). The major source of heavy metals and POPs in the Antarctic is from urbanised areas or islands on the continents with intensive agriculture.

Non-hydrocarbon co-pollutants may be introduced into the Antarctic environment through oil spills. For example, diesel oil utilised in the Antarctic contains heavy metals and anti-icing agents such as diethylene glycol monomethyl ether and ethylene glycol monomethyl ether (Aislabie et al., 2004). Thus, the presence of heavy metals in the soil environment creates a challenge for degrading diesel due to their highly toxic effects on petroleum-degrading bacteria. Furthermore, oil spills tend to persist longer in the Antarctic environment owing to the chronically low temperatures, limited nutrient availability and dry conditions, which slow down the rates of microbial processes and abiotic degradation (Aislabie et al., 2006; Ahmad et al., 2013; Roslee et al., 2020). Not with standing this, the use of microorganisms for remediating environmental pollutants such as petroleum hydrocarbons is receiving increasing attention as it causes less damage to the environment, is economically desirable and can completely remove harmful pollutants (Ahmad et al., 2013; Ibrahim et al., 2015; Nawawi et al., 2016; Al-Hadithi et al., 2017). In the present study, the ability of psychrotolerant bacterial strains Arthrobacter sp. AQ5-05 and AQ5-06, originally obtained from Antarctica to degrade diesel oil in the presence of various heavy metal co-pollutants was tested.

\section{Materials and Methods}

Sample collection: The isolates Arthrobacter sp. strains AQ5-05 and AQ5-06 used in this study were originally isolated from Antarctic soil obtained on King George Island, South Shetland Islands (Lee et al., 2018). The isolates were maintained in glycerol stock at a $-80^{\circ} \mathrm{C}$ at Eco-Remediation Technology Laboratory, Department of Biochemistry, Faculty of Biotechnology and Science Biomolecules, Universiti Putra Malaysia until further use.

Diesel medium: Diesel fuel used for the experiment was obtained from a Petronas filling station in Selangor, Malaysia, and was used as the sole carbon source (3\%) in all experiments. Bushnell-Haas $(\mathrm{BH})$ broth was utilised for screening dieseldegrading bacteria growth in the presence of heavy metals (Bushnell and Haas, 1941). The pH of the medium was adjusted to $7.0 \pm 0.2$ at $25^{\circ} \mathrm{C}$ prior to sterilisation. In order to ascertain the ability of the strains to use diesel oil as the only carbon source, an uninoculated $\mathrm{BH}$ broth was used as control.

Effects of heavy metals on diesel metabolism of strains $A Q 5$ 05 and AQ5-06: The effects of heavy metals Arsenic (As), silver $(\mathrm{Ag})$, cadmium $(\mathrm{Cd})$, cobalt $(\mathrm{Co})$, chromium $(\mathrm{Cr})$, copper $(\mathrm{Cu})$, mercury $(\mathrm{Hg})$, nickel $(\mathrm{Ni})$ and lead $(\mathrm{Pb})$ on the growth and diesel degradation activity of two strains were tested by growing them in $100 \mathrm{ml} \mathrm{BH}$ medium in a $250 \mathrm{ml}$ conical flask containing diesel with $1 \mathrm{ppm}$ of heavy metal ions. The cultures were incubated at $10^{\circ} \mathrm{C}$ for $240 \mathrm{hr}$ on a rotatory shaker at $150 \mathrm{rpm}$. The diesel-degrading activity of each bacterial isolate was monitored at 24-hr interval. Bacterial growth was determined by measuring the optical density at $600 \mathrm{~nm}$ using a spectrophotometer (U.V mini 1240 Shimazdu, Japan), while diesel degradation was measured gravimetrically (Marquez-Rocha et al., 2001; Patowary et al., 2017). Heavy metals inhibiting the growth and degradation ability of the isolates were selected for more detailed studies.

Effects of different concentrations of heavy metals on dieseldegrading activities: Concentrations of heavy metals that impaired the growth and diesel degradation of two strains in the range $0.2,0.4,0.6,0.8$ and 1.0 ppm were used to further study the impacts on diesel degradation. The cultures were incubated at $10^{\circ} \mathrm{C}$ for $240 \mathrm{hr}$ on a rotatory shaker at $150 \mathrm{rpm}$. The dieseldegrading activity of each bacterial isolate was monitored at $24 \mathrm{hr}$ interval. Bacterial growth was determined by measuring the optical density at $600\left(\mathrm{OD}_{600}\right)$, while diesel degradation was measured gravimetrically (Marquez-Rocha et al., 2001; Patowary 
et al., 2017). Briefly, the residual hydrocarbon in diesel oil from each culture was extracted using a solvent extraction method by destructive sampling of triplicate flask containing culture. $n$ Hexane (1:1 media to $n$-hexane) was used to separate the cellular material. After evaporation, the remaining residual hydrocarbon in diesel was quantified gravimetrically.

Inhibitory concentration $\mathbf{5 0}\left(\mathbf{I}_{50}\right)$ : The metal ion concentration achieving $50 \%$ degradation inhibition $\left(\mathrm{IC}_{50}\right)$ was assessed. Graphpad Prism v.5. software was used for data analysis using mean and standard deviation (STDEV) values.

Statistical analysis: All experiments were performed in triplicate. The data obtained are presented as mean \pm standard deviation. Statistical analysis was carried out using ANOVA and diesel degradation was analysed based on degradation percentage.

\section{Results and Discussion}

The ability of Arthrobacter sp. strains AQ5-05 and AQ5-06 to degrade diesel oil were evaluated by incubating both strains in $\mathrm{BH}$ medium supplemented with $0.5 \%$ diesel as the sole carbon source at $10^{\circ} \mathrm{C}$ and $150 \mathrm{rpm}$. Strain AQ5-06 showed enhanced in comparison to growth $\left(\mathrm{OD}_{600}=0.956\right)$ after $168 \mathrm{hr}$ incubation period AQ5-05 $\left(\mathrm{OD}_{600}=0.758\right)$ (Fig. 1). Gravimetric analysis showed that strain AQ5-06 degraded $37.5 \%$ diesel, while strain AQ5-05 degraded 34.5\%. Arthrobacter strains AQ5-05 and 06 are cold-tolerant strains isolated from chronically polluted Antarctic soil that can utilise diesel as their sole carbon source and energy, hence, are capable of degrading diesel efficiently. After an initial acclimatisation period of $24 \mathrm{hr}$, both strains achieved maximum diesel degradation within 7 day. Arthrobacter and Rhodococcus have been identified among the major

- AQ5-06 Diesel degradation - - AQ5-05 Diesel degradation $\because$ AQ5-06 Bacterial growth $\neg$ AQ5-05 Bacterial growth

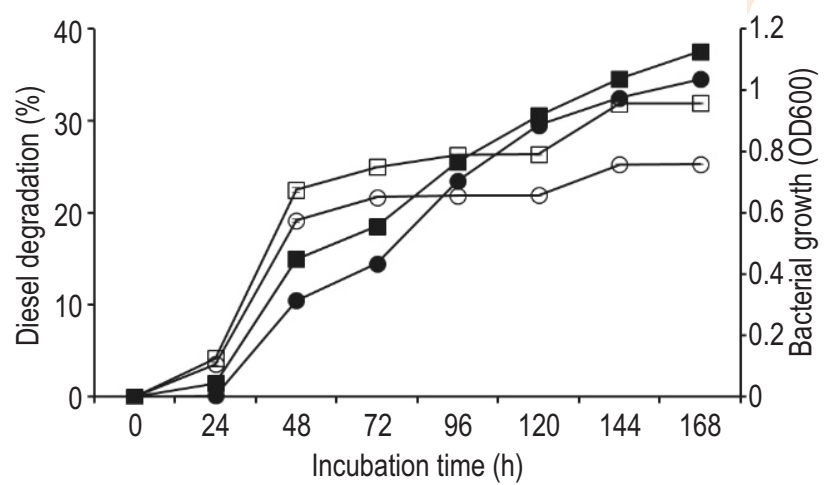

Fig. 1 : Growth of strains AQ5-05 (empty circle), and AQ5-06 (empty square) in $\mathrm{BH}$ media containing $0.5 \%(\mathrm{v} / \mathrm{v})$ diesel as the sole carbon source at $10^{\circ} \mathrm{C}$, and diesel degradation by strains AQ5-05 (filled circle), and AQ5-06 (filled square) based on gravimetric analysis $(n=3)$. Error bars represent mean \pm S.D. hydrocarbon-degrading bacteria (Whyte et al., 2002). Studies of non-polluted soils have also revealed psychrophilic or coldtolerant members of Arthrobacter to be important members of bacterial communities in Antarctic soils (Dsouza et al., 2015). Margesin et al. (2013) and Lee et al. (2018) also reported that Arthrobacter sp. strains are capable of degrading petroleum hydrocarbons (n-alkanes and phenol) at low temperature.

The results of various heavy metal ions on growth and diesel degradation by Arthrobacter sp. strains AQ5-05 and AQ506 were evaluated. The data obtained confirmed that mercury and silver significantly impeded the growth $(F(8,18)=206.123$, $p<0.001$ and $F(8,18)=156.608, p<0.001$, respectively) and diesel degradation activity of both strains $(F(9,10)=105.21$, $p<0.001$, and $F(9,20)=246.021, p<0.001$, respectively) (Fig. 2). However, no significant difference was observed between the effects of mercury and silver for both strains $(p>0.001)$. Furthermore, Tukey's HSD showed that there was no significant difference in the mean values obtained after exposure to mercury ( $M=0.300, S D=0.001)$ and silver $(0.430, S D=0.007)$. In the absence of heavy metal ions, strains AQ5-05 and AQ5-06 degraded $37.3 \%$ and $46.6 \%$ of the initial diesel concentration.
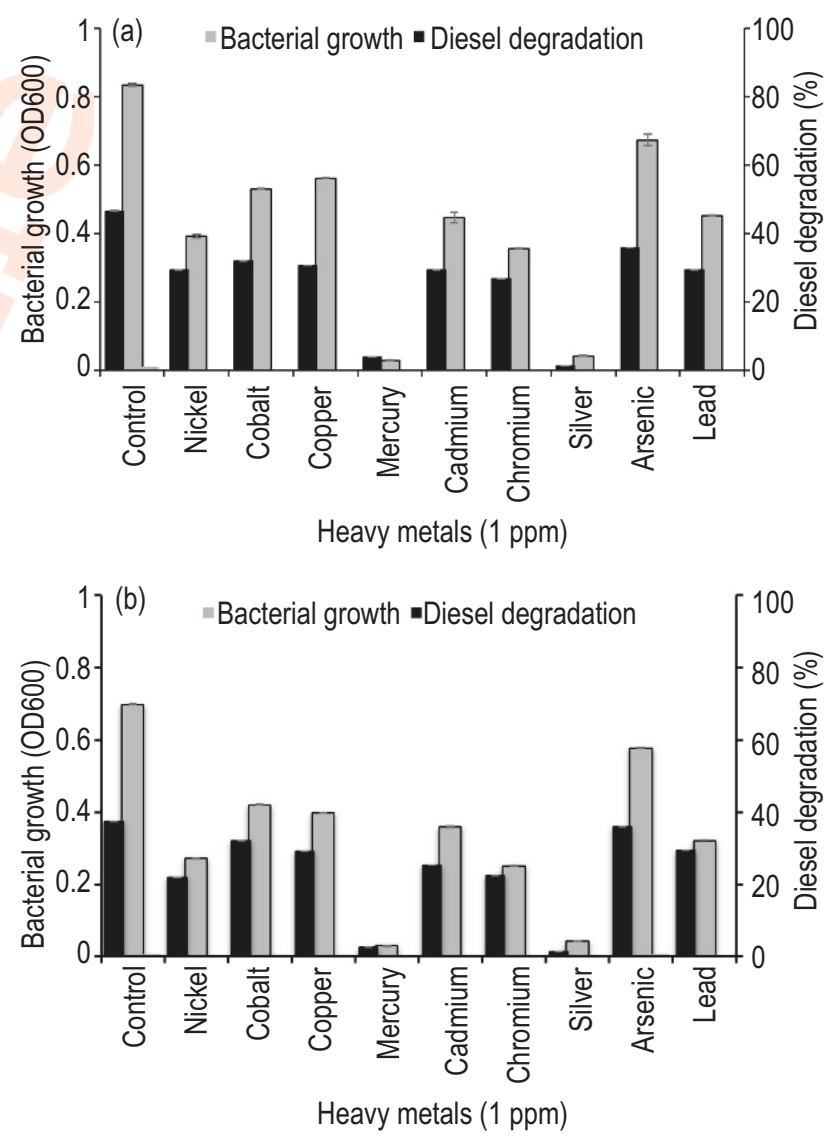

Fig. 2 : Effects of various heavy metal ions on growth and degradation activity of strains AQ5-06 (a) and AQ5-05 (b). Error bars represent mean \pm S.D. 
Degradation was reduced to about $4 \%$ of initial diesel concentration in the presence of either mercury or silver. This result is consistent with the studies of Ahmad et al. (2018) and Zakaria et al. (2018), who reported that mercury, silver and cadmium significantly inhibited the growth and phenol degradation activities of Arthrobacter bambusae strain A5-003 and Rhodococcus baikomurensis strain AQ5-001, respectively.

The activities of Antarctic microbial communities as well as the enzymes involved in different metabolic processes are affected by heavy metals (Hong et al., 2012), including impairment of microbial diesel degradation (Kandeler et al., 1996; Riis et al., 2002). Immediately after oil spill, heavy metals are readily available and bioaccumulate in soil and marine biota. Lead, nickel, vanadium, zinc and cadmium are the most often post oil spills heavy metals (Mustafa et al., 2015). Thus, Ni, Cd and $\mathrm{Zn}$ were included in the heavy metals of importance for this study. Furthermore, burning of fossil fuel significantly increases the level of heavy metals in the environment (Adriano, 2001). In addition, the results showed that strains AQ5-05 and AQ5-06 effectively degraded diesel in the presence of $1 \mathrm{ppm}$ of $(\mathrm{As}, \mathrm{Cd}$, $\mathrm{Co}, \mathrm{Cu}, \mathrm{Ni}$ and $\mathrm{Pb}$ as compared to the control (diesel) $(F(9,10)=$ 10203.824, $p<0.001$ and $F(9,10)=98312$. 0781, $p<0.001$,
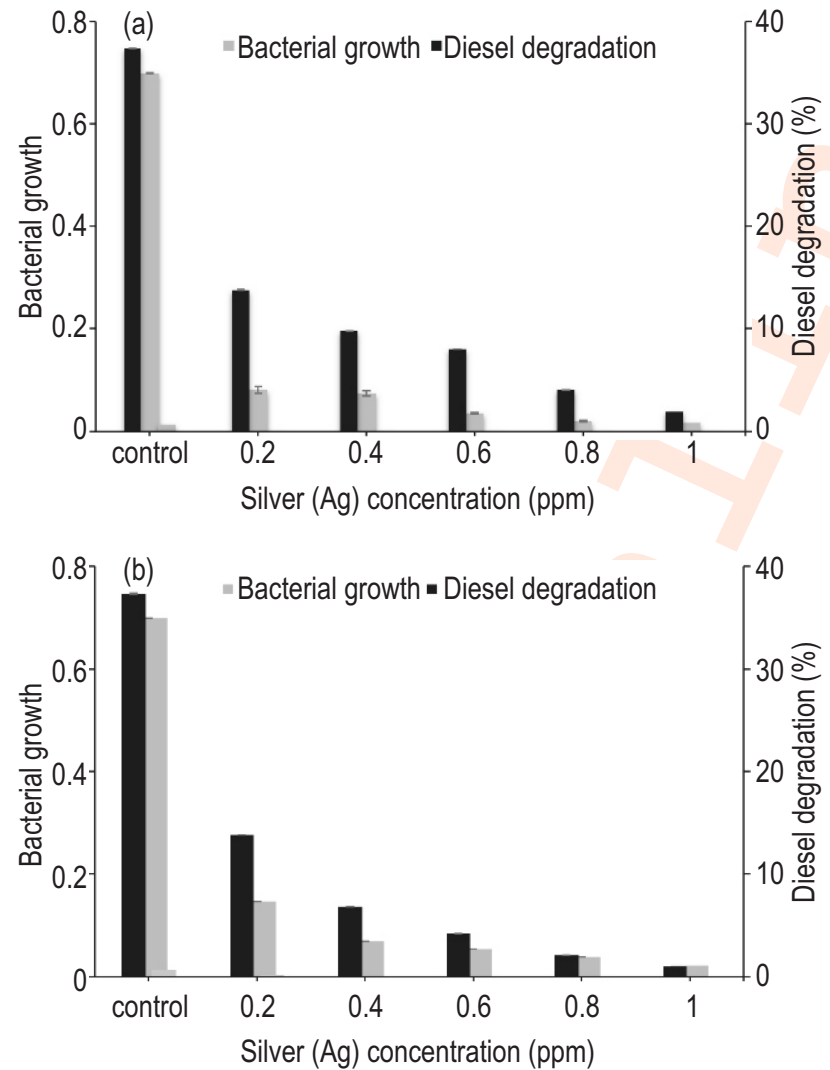

Fig. 3 : Effect of silver on diesel degradation and bacterial growth of (a) Arthrobactersp. strain AQ5-05 and (b)AQ5-06. Values represent mean \pm SEM. respectively). Also, Tukey's HSD showed that there was no significant difference in mean values between the degradation in the control $(\mathrm{M}=0.699, \mathrm{SD}=0.001$ and $\mathrm{M}=0.836, \mathrm{SD}=0.004)$ respectively and in the presence of the tested heavy metals. The present data confirmed that both strains could degrade diesel even in the presence of toxic heavy metal ions. These data are consistent with the reports of Abou-Shanab et al. (2007) and Tomova et al. (2015) for Arthrobacter sp. strain AY509239 and Bacillus sp. strain Vi 1, respectively. The results of this study is also in agreement with Gran-Scheuch et al. (2017) who, reported that isolated bacterial strain Sphingobium xenophagum D43FB was capable of degrading phenanthrene in the presence of heavy metals present in diesel.

Several studies have elucidated various mechanisms by microbes that reduce the effects of heavy metal exposure in their natural habitats (Bruins et al., 2000; Nies, 2003; Haferburg and Kothe, 2007). Since heavy metals generally have similar toxicity mechanisms, multiple resistance is a typical phenomenon among heavy metal resistant microbes (Nath et al., 2012). The three most common resistance mechanisms employed are efflux of toxic metal ions from bacterial cells; enzymatic transformation of metals and metal-binding proteins integrating heavy metals to be
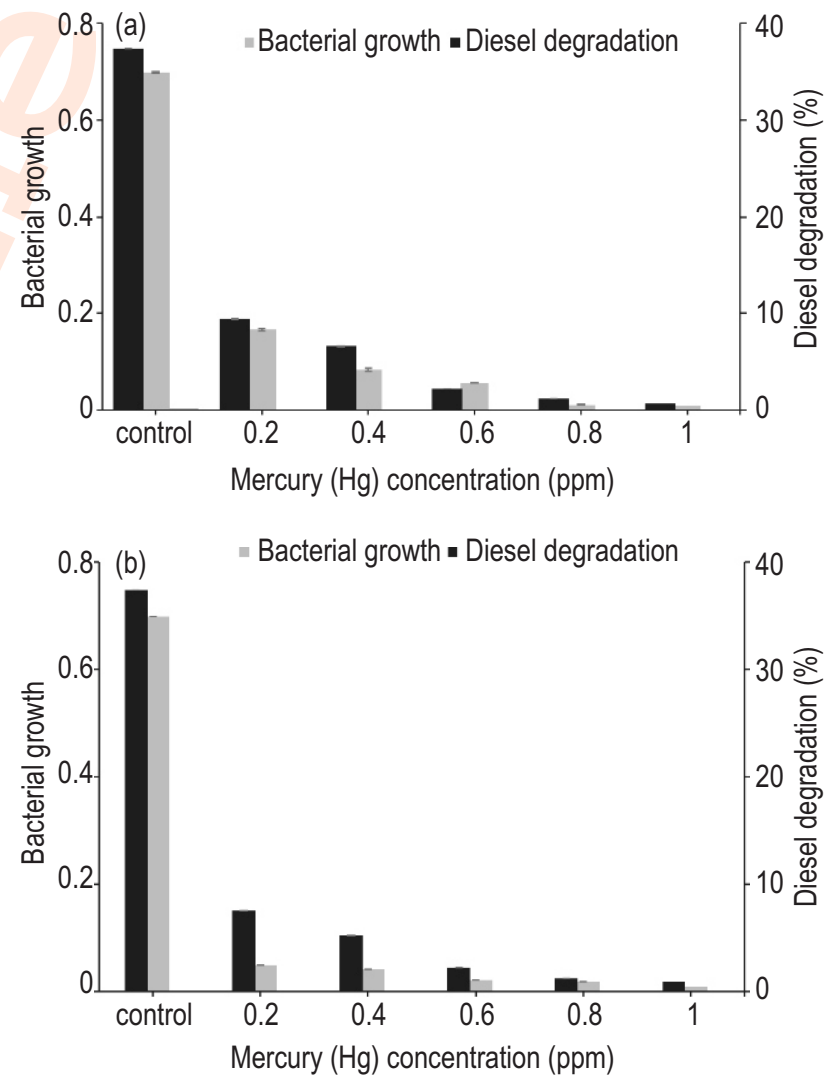

Fig. 4 : Effect of mercury on diesel degradation and bacterial growth of (a) Arthrobacter sp. strain AQ5-05 and (b) AQ5-06. Values represent mean \pm SEM. 
harmless to the cell (Dziewit and Drewniak, 2016). Heavy metal resistant microbes can therefore play a significant role in the bioremediation of heavy metal polluted soils (Ray and Ray, 2009).

Exposure to silver and mercury inhibit diesel degradation in both strains. Therefore, these two heavy metals were selected for further studies to determine the concentration at which degradation inhibition occurred (Fig. 3). The concentrations of silver and mercury were varied from 0.2 to $1.0 \mathrm{ppm}$. The results of the effects of various concentrations of silver on diesel degradation and growth of strains AQ5-05 and AQ5-06 revealed that concentrations of silver and mercury from 0.4 to $1.0 \mathrm{ppm}$ inhibited diesel degradation $(F(9,10)=105.21, p<0.001$ and $F$ $(9,20)=246.021, p<0.001$, respectively). The data indicated that silver had began to inhibit strains AQ5-05 and AQ5-06 from degradation diesel, and reduced bacterial growth at 0.6 and 0.4 ppm (inhibiting diesel degrading efficiency to $8.0 \%$ and $6.8 \%$ ), respectively $(F(4,5)=4589.269, p<0.001$ and $F(4,5)=3461$. $021, p<0.001$, respectively) (Fig. 3). Inhibition of mercury strains $\mathrm{AQ5}-05$ and $\mathrm{AQ5}-06$ began at 0.8 and $0.6 \mathrm{ppm},(F(4,5)=$ $5539.795, p<0.001$ and $F(4,5)=3854.501 .021, p<0.001$ (Fig. 4 ).
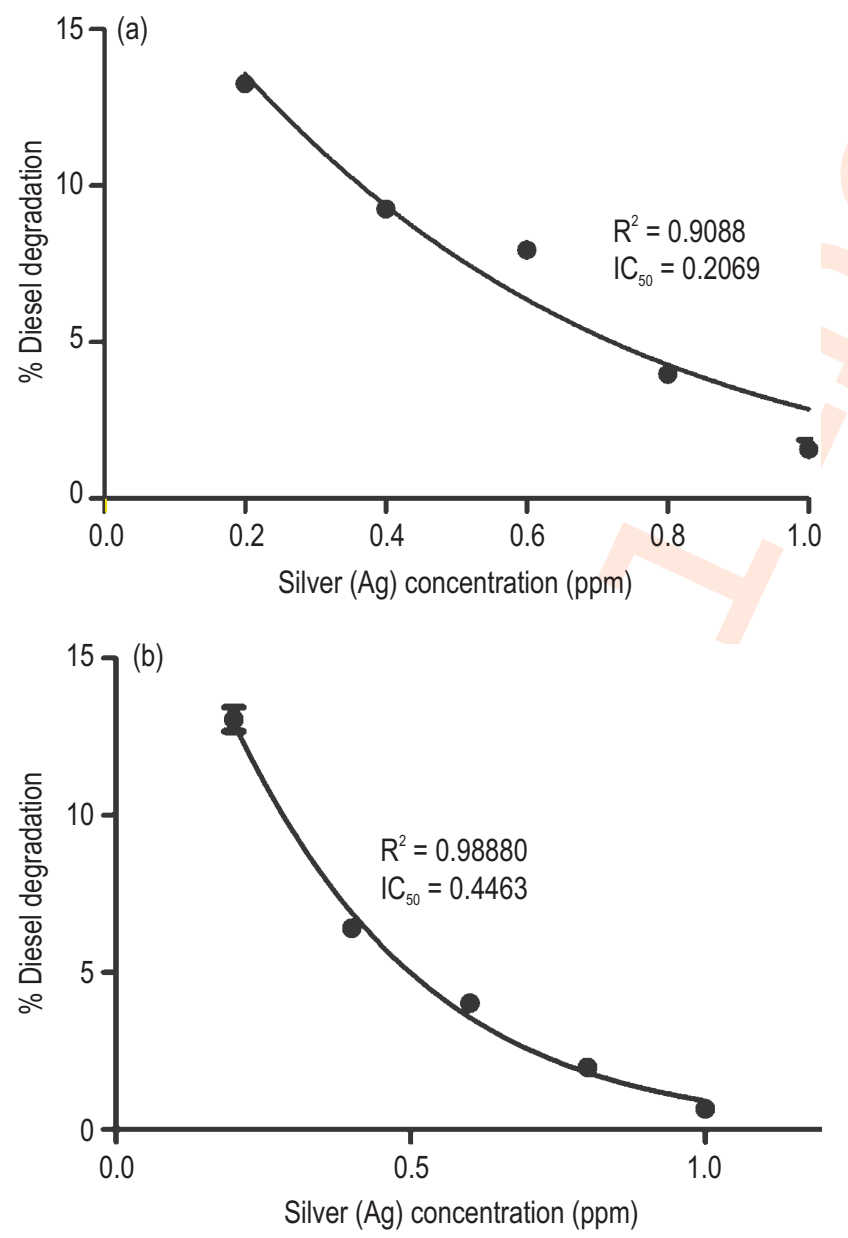

Fig. 5 : $I_{50}$ of silver on diesel degradation of (a)AQ5-05 and (b)AQ5-06.
Toxicity of metals like silver occurs due to dislodging of essential metal ions from their normal binding sites (Nies, 1999; Bruins et al., 2000). Silver ions can also disrupt the link between cytoplasmic membrane and cell wall in Gram-positive bacteria (Feng et al., 2009). Silver and mercury are toxic due to high mobility of their ions and, if they enter the food chain, can cause deleterious effect on human health (Goris et al., 2001). At toxic concentrations, silver and mercury highly affect both structural and permeability properties of internal membranes and organelles, thereby inhibiting enzymatic activities and causing nutrient imbalances (Green et al., 2003). Silver can also alter the membrane structure by adhering to bacterial cells making the membrane permeable, resulting in accumulation of silver in the cell, and damage DNA finally leading to (Morones et al., 2005). Mercury is soluble in lipids and can easily bind to proteins containing sulfhydryl groups in the cell membrane resulting in cytotoxicity (Robinson and Tuovinen, 1984). Both silver and mercury have been shown to have an inhibitory effect on the action of alkane monooxygenase compounds that are primarily involved in diesel degradation.
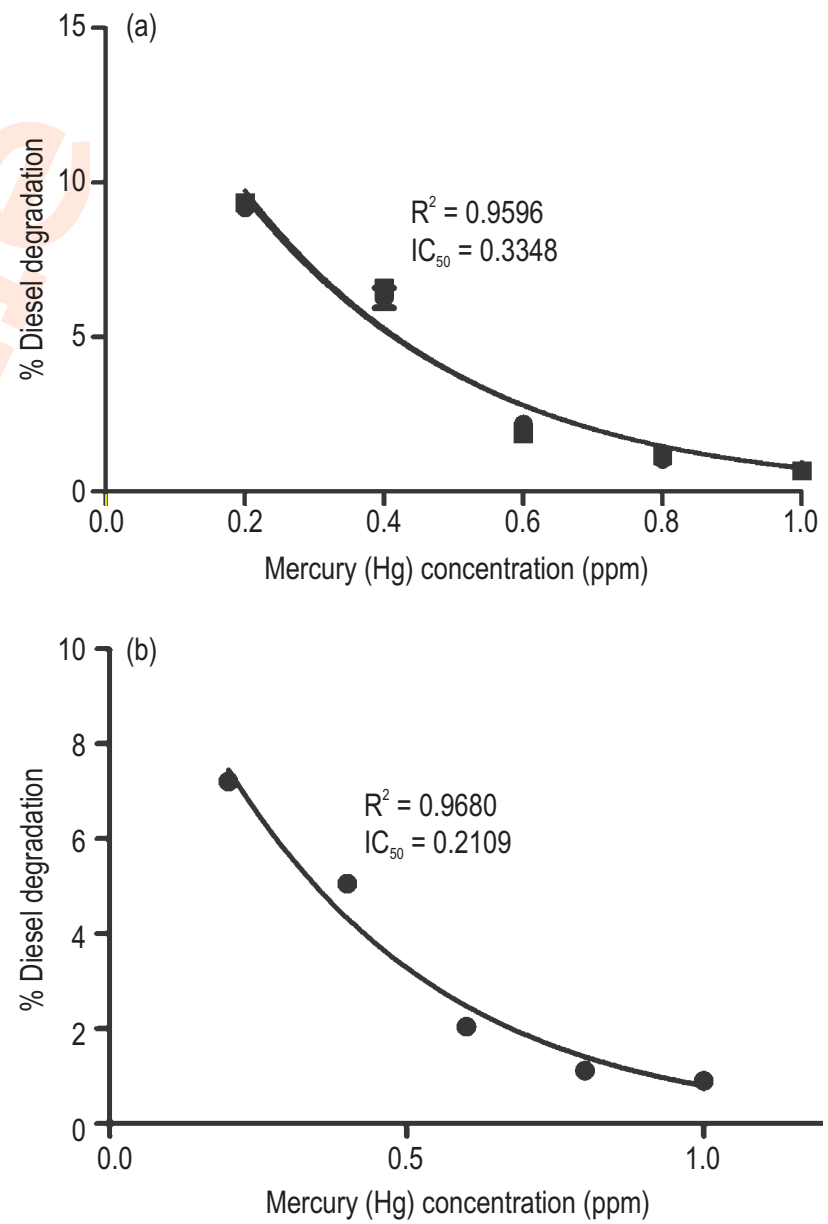

Fig. 6 : IC $C_{50}$ of mercury on diesel degradation of (a) strain AQ5-06 and (b) AQ5-06. 
The inhibitory concentration $\left(\mathrm{IC}_{50}\right)$ is the measure of microbial tolerance to a substance (Sebaugh, 2011). The $I C_{50}$ inhibiting the growth and degradation of strains AQ5-05 and AQ506 was evaluated using Graphpad prism software. Diesel degradation by strains AQ5-05 and AQ5-06 was inhibited by silver at $0.2 \mathrm{ppm}$ and $0.4 \mathrm{ppm}$ respectively (Fig. 5).

In this study, it was observed that $0.2 \mathrm{ppm}$ or $0.4 \mathrm{ppm}$ of silver had reduced diesel degradation by $13.8 \%$ and $5.2 \%$ (AQ505 and AQ5-06). Ahmad et al. (2018) reported an $\mathrm{IC}_{50}$ of $\mathrm{Ag}$ of 0.53 ppm for degradation by Arthrobacter bambusae strain AQ5-003, similar to that found in the present study. The $I_{50}$ values of mercury in this study, was 0.3 ppm and 0.2 ppm for strains AQ5-05 and AQ5-06, which was similar to that reported by Zakaria et al. (2018).

In conclusion, it is commendable to note that the two coldadapted bacteria are competent of tolerating heavy metals present in the Antarctic ecosystem. This finding supports that these strains have potential for bioremediation of diesel oil polluted soils and waste waters in Antarctica and other cold environments, even in the presence of some heavy metals.

\section{Acknowledgments}

This project was financially supported by the Putra-IPM fund under the research grant attached to S.A Ahmad (GPMatching Grant/2016/9300430, GP-Matching Grant/2017/ 9300436, GPM-2018/9660000, GPM-2019/9678900 and 6300247-YPASM Smart Partnership Initiative) disbursed by Universiti Putra Malaysia (UPM) and Yayasan Penyelidikan Antartika Sultan Mizan (YPASM). P. Convey is supported by NERC core funding to the BAS 'Biodiversity, Evolution and Adaptation' Team. The authors would like to thankAssoc. Prof. Dr. Siti Aisyah Alias (University of Malaya) and Professor Gerardo Gonzalez-Rocha (Universidad de Concepcion) for their help. The Tertiary Education Trust Fund (TETFUND) through Gombe State University, Gombe, Nigeria is thanked for financial sponsorship to Mansur Abdulrasheed. We also thank the Public Service Department of Malaysia (JPA) for granting a master's programme scholarship to Ahmad FareezAhmad Roslee.

\section{References}

Abou-Shanab, R.A., P. van Berkum and J.S. Angle: Heavy metal resistance and genotypic analysis of metal resistance genes in Gram-positive and Gram-negative bacteria present in Ni-rich serpentine soil and in the rhizosphere of Alyssum murale. Chemosphere, 68, 360-367 (2007).

Adriano, D.C.: Trace elements in terrestrial environments: Biogeochemistry, bioavailability and risks of metals. $2^{\text {nd }}$ Edn., Springer, New York, 867 (2001)

Ahmad, S.A., G. Asokan, N.A. Yasid, N.M. Nawawi, K. Subramaniam, N.N. Zakaria and M.Y. Shukor: Effect of heavy metals on biodegradation of phenol by Antarctic bacterium: Arthrobacter bamsusae strain AQ5-003. Malays. J. Biochem. Mol. Biol., 21,
47-51 (2018).

Ahmad, S.A., M.Y. Shukor, N.A. Shamaan, W.P. Mac Cormack and M.A. Syed: Molybdate reduction to molybdenum blue by an Antarctic bacterium. BioMed. Res. Int., 2013, 871941 (2013).

Aislabie, J.M., M.R. Balks, J.M. Foght and E.J. Waterhousez: Hydrocarbon spills on Antarctic soils: Effects and management. Environ. Sci. Technol., 38, 1265-1274 (2004).

Aislabie, J., D.J. Saul and J.M. Foght: Bioremediation of hydrocarboncontaminated Polar soils. Extremophiles, 10, 171-179 (2006).

Al-Hadithi, H.T., E.A. Al-Razzaq and G.F. Fadhil: Bioremediation of polycyclic aromatic hydrocarbons by Acinetobacter species isolated from ecological sources. J. Environ. Biol., 38, 785-789 (2017).

Bargagli, R.: Environmental contamination in Antarctic ecosystems: Sci. Total Environ., 400, 212-226 (2008).

Bicca, F.C., L.C. Fleck and M.A.Z. Ayub: Production of biosurfactant by hydrocarbon degrading Rhodococcus ruber and Rhodocuccus erythropolis. Rev. Microbiol., 30, 231-236 (1999).

Bruins, M.R., S. Kapil and F.W. Oehme: Microbial resistance to metals in the environment. Ecotoxicol. Environ. Saf., 45, 198-207 (2000).

Bushnell, L.D. and H. Haas: The utilization of certain hydrocarbons by microorganisms. J. Bioteriol., 41, 653-673 (1941).

Corsolini, S.: Industrial contaminants in Antarctic biota. J. Chromat., 1216, 598-612 (2009).

Darham, S., C. Gomez-Fuentes, A. Zulkharnain, S. Sabri, N. CalistoUlloa, N. Ramirez-Moreno and S.A. Ahmad: Isolation and identification of molybdenum-reducing cold-adapted marine bacteria isolated from Bernardo O'higgins Riquelme base station, Antarctica. Malays. J. Biochem. Mol. Biol., 22, 8-15 (2019).

Dsouza, M., M. W. Taylor, S. J. Turner and J. Aislabie: Genomic and phenotypic insights into the ecology of Arthrobacter from Antarctic soils. BCM Genomics, 16, 1-18 (2015).

Dziewit, L. and L. Drewniak. Heavy metals resistance, metabolism and transformation-genomic, metagenomics and metatranscriptomic studies. In: Microbial biodegradation: from omics to function and application (Ed.: J. Dlugonski). Caister Academic Press, Poole, pp. 13-26 (2016).

Feng, Q.L., J. Wu, G.Q. Chen, F.Z. Cui, T.N. Kim and J.O. Kim: A mechanistic study of the antibacterial effect of silver ions on Escherichia coli and Staphylococcus aureus. J. Biomed. Mat. Res., 52, 662-668 (2009).

Gallego, J.L.R., J. Loredo, J.F. Llamas, F. Vázquez and J. Sánchez: Bioremediation of diesel-contaminated soils: evaluation of potential in-situ techniques by study of bacterial degradation. Biodegrad., 12, 325-335 (2001).

Goris, J., V.P.T. De-Coenye, B. Hoste, D. Janssens, H. Brim and P. Vandamme: Classification of metal-resistant bacteria from industrial biotopes as Ralstonia campinensis sp. nov., Ralstonia metallidurans sp. nov. and Ralstonia basilensis Steinle et al. 1998 emend. Inter. J. Syst. Evolut. Microbiol., 51, 1773-1782 (2001).

Gran-scheuch, A., E. Fuentes, D.M. Bravo, J.C. Jimenez and J.M. PerezDonoso: Isolation and characterization of phenanthrene degrading bacteria from diesel fuel-contaminated Antarctic soils. Front. Microbiol., 8, 1-12 (2017).

Green, C.E., R.L. Chaney and J. Bouwkamp: Interactions between cadmium uptake and phytotoxic levels of zinc in hard red spring wheat. J. Plant Nutrit., 26, 417-430 (2003).

Haferburg, G. and E. Kothe: Microbes and metals: Interactions in the environment. J. Basic Microbiol., 47, 453-467 (2007). 
Hong, S., T. Soyol-Erdene, H. Hwang, S. Hong, S. Hur and H. Motoyama: Evidence of global-scale $\mathrm{As}, \mathrm{Mo}, \mathrm{Sb}$, and Ti atmospheric pollution in the Antarctic snow. Environ. Sci. Technol., 46, 11550-11557 (2012).

Ibrahim, S., M.Y. Shukor, K.A. Khalil, M.I.E. Helmi, M.A. Syed and S.A. Ahmad: Application of response surface methodology for optimising caffeine-degrading parameters by Leifsonia sp. strain SIU. J. Environ. Biol., 36, 1215-1221 (2015).

Kandeler, E., C. Kampichler and O. Horak. Influence of heavy metals on the functional diversity of soil microbial communities. Biol. Fert. Soils., 23, 299-306 (1996).

Lee, G.L., S.A. Ahmad, N.A. Yasid, A. Zulkharnain, P. Convey, W.L. Johari and M.Y. Shukor: Biodegradation of phenol by cold-adapted bacteria from Antarctic soils. Polar Biol., 41, 553-562 (2018).

Lee, I.S., M. Hagwall, J.J. Delfino and P.S. Raotvgzz: Partitioning of polycyclic aromatic hydrocarbons from diesel fuel into water. Environ. Sci. Technol., 26, 2104-2110 (1992).

Marquez-rocha, F.J., V. Hernandez-rodriguez and M.L. Teresa. Biodegradation of diesel oil in soil by a microbial consortium. Water Air Soil Poll., 128, 313-320 (2001).

Margesin, R., C. Moertelmaier and J. Mair. Low-temperature biodegradation of petroleum hydrocarbons ( $n$-alkanes, phenol, anthracene, pyrene) by four actinobacterial strains. Int. Biodeter. Biodegrad., 84, 185-191 (2013).

Mazuki, T.A.T., M.Y. Shukor and S.A. Ahmad: Bioremediation of phenol in Antarctic: A mini review. Malays. J. Biochem. Mol. Biol., 22, 1-6 (2019).

Morones, J.R., J.L. Elechiguerra, A. Camacho, K. Holt, J.B. Kouri, J.T. Ramirez and M.J. Yacaman: The bactericidal effect of silver nanoparticles. Nanotechnology, 16, 2346-2353 (2005).

Murthy, S., G. Bali and S.K. Sarangi: Effect of lead on growth, protein and biosorption capacity of Bacillus cereus isolated from industrial effluent. J. Environ. Biol., 35, 407-411 (2014).

Mustafa, A.D., H. Juahir, K. Yunus, M.A. Amran, C.N. Che-Hasnam, F. Azaman, I.Z. Abidin, S.H. Azmee and N.H. Sulaiman: Oil spill related heavy metal: A review. Malaysian J. Analy. Sci., 19, 13481360 (2015).

Nath, S., B. Deb and I. Sharma: Isolation and characterization of cadmium and lead resistant bacteria. Global Advan. Res. J. Microbiol., 1, 194-198 (2012).

Nawawi, N.M., S.A. Ahmad, M.Y. Shukor, M.A. Syed, K.A. Khalil, N.A. Ab Rahman, F.A. Dahalan and A.L. Ibrahim. Statistical optimisation of improvement of phenol degradation by Rhodococcus sp. NAM 81. J. Environ. Biol., 37, 443-451 (2016).

Nies, D.H.: Microbial heavy-metal resistance. Appl. Microbiol. Biotechnol., 51, 730-731 (1999).

Nies, D.H.: Efflux-mediated heavy metal resistance in prokaryotes. FEMS Microbiol. Revi., 27, 313-339 (2003).

Patowary, K., R. Patowary, M.C. Kalita and S. Deka: Characterization of biosurfactant produced during degradation of hydrocarbons using crude oil as sole source of carbon. Front. Microbiol., 8, 1-14 (2017).

Pandey, S., P. Saha, S. Biswas and T.K. Maiti: Characterization of two metal resistant Bacillus strains isolated from slag disposal site at Burnpur, India.. J. Environ. Biol., 32, 773-779 (2011).

Prus, W., M.J. Fabianska and R. Labno: Geochemical markers of soil anthropogenic contaminants in Polar scientific stations nearby (Antarctica, King George Island). Sci. Total Environ., 518, 266-279 (2015).

Ray, S.A. and M.K. Ray: Bioremediation of heavy metal toxicity-with special reference to Chromium. Al Ameen J. Med. Sci., 2, 57-63 (2009).

Riis, V., W. Babel and P.H. Oscar: Influence of heavy metals on the microbial degradation of diesel fuel. Chemosphere, 49, 559-568 (2002).

Robinson, J.B. and O.H. Tuovinen: Mechanisms of microbial resistance and detoxification of mercury and organomercury compounds: Physiological, biochemical and genetic analyses. Microbiol. Rev., 48, 95-124 (1984).

Roslee, A.F.A., N.N. Zakaria, P. Convey, A. Zulkharnain, G.L.Y. Lee, C. Gomez-Fuentes and S.A. Ahmad: Statistical optimisation of growth conditions and diesel degradation by the Antarctic bacterium, Rhodococcus sp. strain AQ5 07. Extremophiles, 24, 277-291 (2020).

Ruberto, L., W. Patricio and M. Cormack: Psychrotolerant hydrocarbondegrading Rhodococcus strains isolated from polluted Antarctic soils. Ant. Sci., 17, 47-56 (2005).

Santos, I.R., E. Silva-Filho, C.E.G.R. Schaefer, M.R. Albuquerque-Filho and L. Campos: Heavy metal contamination in coastal sediments and soils near the Brazilian Antarctic Station, King George Island. Marine Pollut. Bull., 50, 185-194 (2005).

Sebaugh, J.L.: Guidelines for accurate EC50//C50 estimation. Pharm. Stat., 10, 128-134 (2011).

Sha'arani, S.A.W., M.Y. Shukor, A.A. Basirun and S.A. Ahmad: Screening of three phenol-degrading bacteria for copper bioremover. J. Environ. Biol., 40, 1045-1051 (2019).

Snape, I., C.E. Morris and C. Cole: The use of permeable reactive barriers to control contaminant dispersal during site remediation in Antarctica. Cold Reg. Sci. Technol., 32, 157-174 (2001).

Tomova, I., M. Stoilova-Disheva, I. Lazarkevich and E. VasilevaTonkova: Antimicrobial activity and resistance to heavy metals and antibiotics of heterotrophic bacteria isolated from sediment and soil samples collected from two Antarctic islands. Front. Life Sci., 8, 348-357 (2015).

Wang, M., G. Kan, C. Shi, Q. Xie, Y. Huang and Z. Lei: Heavy metal tolerance of an Antarctic bacterial strain $\mathrm{O5}$ and its antioxidant enzyme activity changes induced by $\mathrm{Cu}^{2+}$. Int. Conf. Syst. Biol., 978-1-4577, 303-306 (2011).

Whyte, I.G., A. Schultz, J.B. van Beilen, A.P. Luz, V. Pellizari, D, Labbé, and C.W. Greer: Prevalence of alkane monooxygenase genes in Arctic and Antarctic hydrocarbon-contaminated and pristine soils. FEMS Microbiol. Ecol., 41, 141-150 (2002).

Zakaria, N.N., S.A. Ahmad, N.A. Yasid, G.L.L. Yin, M. Manogaran, K. Subramaniam and M.Y. Shukor: Biodegradation of phenol by Antarctic bacterium Rhodococcus baikonurensis strain AQ5-001 in the presence of heavy metals. Malays. J. Biochem. Mol. Biol., 21, 29-36 (2018).

Zakaria, N.N., A.F.A. Roslee, A. Zulkharnain, C. Gomez-Fuentes, M. Abdulrasheed, S. Sabri, N. Calisto-Ulloa and S.A. Ahmad: Bacterial growth and diesel biodegradation in the presence of As, $\mathrm{Cu}$ and $\mathrm{Pb}$ by Antarctic marine bacteria. Malays. J. Biochem. Mol. Biol., 22, 1-7 (2019).

Zhang, J., L. Han, Y. Ji, J. Wei, G. Cai, G. Gao, J. Wu and Z. Yao: Heavy metal investigation and risk assessment along the Le'An River from non-ferrous metal mining and smelting activities in Poyang, China. J. Environ. Biol., 39, 536-545 (2018).

Zhou, X.D., C.L. Zhao, T.B. Qu, Y. Wang, T.J. Guo and X.G. Sun: Characteristics and evaluation on heavy metal contamination in Changchun municipal waste landfill after closure. J. Environ. Biol., 36, 857-863 (2015). 